\title{
Effect of Weather Parameters on Crop Growth, Development and Yield of Kharif Cotton Varieties under Extended Sowing Times
}

\author{
K.K. Dakhore ${ }^{1}$ and Y.E. Kadam ${ }^{2 *}$ \\ ${ }^{1}$ AICRPAM Parbhani - 431 401, Maharashtra, India \\ ${ }^{2}$ VNMKV Parbhani - 431 401, Maharashtra, India \\ *Corresponding author
}

\begin{tabular}{|l|}
\hline Ke y w o r d s \\
Cotton varieties, \\
$\begin{array}{l}\text { Sowing times, } \\
\text { Yield, Weather } \\
\text { parameters }\end{array}$ \\
\hline Article Info \\
\hline $\begin{array}{l}\text { Accepted: } \\
\text { xx October } 2018 \\
\text { Available Online: } \\
\text { xx December } 2018\end{array}$ \\
\hline
\end{tabular}

\section{Introduction}

Cotton is one of the most important and widely produced agricultural crop in the world. It is cultivated in almost every continent except Antarctic, and in over 60 countries in the world. In many countries, cotton is one of the primary economic bases
An experiment entitled "Effect of weather parameters on crop growth, development and yield of Kharif Cotton varieties under extended sowing times" was conducted during 2016-17 at Research farm AICRP, Vasantrao Naik Marathwada Krishi Vidyapeeth, Parbhani during Kharif season. The field experiment was lay out in a split plot design with three replications. There were thirty six treatment combinations comprising of four sowing times viz., $24^{\text {th }}, 25^{\text {th }}, 26^{\text {th }}$ and $27^{\text {th }} \mathrm{MW}$ as main plot treatments and three varieties viz. Ajit155, Mallika and Rashi-2 (779) as sub plot treatments. Among the three different varieties of cotton, Ajit-155 and Sowing of cotton during $25^{\text {th }} \mathrm{MW}$ recorded significantly higher growth parameters viz., plant height, number of branches per plant with yield attributing characters viz., number of boll per plant, grain yield, straw and biological yield. The variety Ajit- 155 and sowing time $25^{\text {th }}$ MW was significantly superior over other varieties and sowing times. The highest grain, straw yields and biological yield were recorded with the variety Ajit-155 sown for $25^{\text {th }}$ MW due to increased seed yield (kg ha-1) than other varieties. The result of the study indicated that thermal indices influence at $25^{\text {th }} \mathrm{MW}$ to favorably improved growth and attributes and yield of cotton variety Ajit-155. The rainfall, minimum temperature, RH-I and RH-II has been positively correlated with seed, straw and biological cotton yield of Ajit-155, Mallik and Rashi-2 (779) varieties, while maximum temperature and BSS has negatively correlated of Ajit-155, Mallik and Rashi-2 (779) varieties respectively. A research work on correlation studies between weather parameters and plant characters of cotton crop varieties under extended sowing times is very meager, hence efforts are made to focus light on it. 
grown in an area with rainfall of $600 \mathrm{~mm}$ to $2500 \mathrm{~mm}$. At least $500 \mathrm{~mm}$ (20 in.) of water (rainfall/ irrigation) is required to produce a cotton crop during the season in a constant and regular pattern (Doorenbos and Pruitt, 1984).

The cotton plant is deciduous, indeterminate plant in the genus Gossypium, belongs to family Malvaceae or mallow, which is cultivated in India with different species namely Gossypium arborium L., Gassypium hirsutum L., Gossypium barbadense L. and Gossypium herbaceam L. The most widely grown species world-wide is Gossypium hirsutum which is grown on over $95 \%$ of the world-wide cotton acrage, followed by $G$. barbadense. India is an exception to most countries, with only $30 \%$ of its cotton production area planted to G. hirsutum, $17 \%$ planted to G. arboretum, $8 \%$ G. herbaceum and the remaining are planted to interspesific and intraspecific hybrid (Jadhav 2014).

India has the largest area under cotton in the world, representing 20 to 25 percent of the total global area. It ranks third in terms of production next to China and USA. The area under cotton in India is 118.77 lakh hectares with production of 338 lakh bales and productivity is $484 \mathrm{~kg}$ lint ha-1 and in Maharashtra was 38.27 lakh hectares with production 75.00 lakh bales and productivity is $333 \mathrm{~kg}$ of lint ha-1during 2015-16 (Anonymous, 2015).

Temperature is one of the most important weather parameter which effect the growth and development of cotton crop. Cotton is most sensitive during flowering when temperature begins to rise above $30^{\circ} \mathrm{C}$. Temperature regimes alter boll development, boll size and the maturity period both decreased as the temperature increased. Boll growth decreases significantly and fruit sheds 3-5 days after blossoming at temperatures above $32^{\circ} \mathrm{C}$ (ICAC, 2007). Reddy et al.,
(1998) observed that the species/cultivars that retain fruits at high temperatures would be more productive both in the present-day cotton production environments and even more in future warmer world. Agricultural activities in India are rainfed and weather-dependent practices so fluctuations in weather parameters affect many of the crop yields.

\section{Materials and Methods}

The Field experiment was conducted during 2016-17 at Research farm AICRPAM, Vasantrao Naik Marathwada Krishi Vidyapeeth, Parbhani, during Kharif season. The field experiment was laid out in a split plot design with three replications. There were thirty six treatment combinations comprising of four sowing times viz., $24^{\text {th }}, 25^{\text {th }}, 26^{\text {th }}$ and $27^{\text {th }} \mathrm{MW}$ as main plot treatments and three varieties viz. Ajit-155, Mallika and Rashi-2 (779) as sub plot treatments.. The gross and net plot sizes were $7.2 \mathrm{~m} \mathrm{x} 5.4 \mathrm{~m}$ and $5.4 \mathrm{~m} \mathrm{x}$ $4.2 \mathrm{~m}$, respectively. A spacing of $120 \mathrm{~cm} \mathrm{x} 45$ $\mathrm{cm}$ was adopted by using 1.5 to $3 \mathrm{~kg}$ seed $\mathrm{ha}^{-1}$. A recommended dose of fertilizer (80:40:40 $\mathrm{kg} \mathrm{N}, \mathrm{P}, \mathrm{K} \mathrm{ha}^{-1}$ ) was applied uniformly to all the treatments.

The periodical observations on growth, micrometeorological parameters and yield contributing characters were recorded at regular interval of 14 days and at harvest. To assess the treatment effects and correlation amongst weather parameters and plant characters of cotton varieties under extended sowing times were worked out. Data of weather parameters growing period of cotton trial during 2016 presented in (Table 3).

\section{Results and Discussion}

\section{Growth studies}

The biometric observations of cotton were recorded on various growth characters viz., 
plant height, number of branches per plant and number of bolls per plant at regular interval of 14 days and at harvest.

\section{Plant height (cm)}

The data in respect of mean periodical plant height of cotton as influenced by different treatments are presented in Table 1. It was observed that the mean plant height increased with advancement in the age of the crop till harvest. The mean initial plant height was $27.67 \mathrm{~cm}$ at 45 days and increased up to $138.54 \mathrm{~cm}$ at harvest.

The mean plant height was significantly influenced by different sowing times. The kharif cotton sown during $25^{\text {th }} \mathrm{MW}$ has recorded maximum plant height at harvesting stage $(145.7 \mathrm{~cm})$. This might be due to congenial climatic condition for better germination and further growth and development of kharif cotton crop. Among the sowing times, cotton sown during $25^{\text {th }} \mathrm{MW}$ attained maximum plant height $(145.7 \mathrm{~cm})$ and lowest plant height $130.9 \mathrm{~cm}$ of sown in $27^{\text {th }}$ MW. Similar result was Awan et al., (2011)

The mean plant height was significantly influenced up to harvest due to different varieties (Table 1). The maximum plant height was observed at harvest stage with Ajeet-155 $(140.13 \mathrm{~cm})$ over rest of the varieties. Thus, the period of grand growth was observed between 45 to 105 days.

The interaction between sowing time and varieties at DAS were found significant (Table 1).

\section{Mean number of branches per plant}

The data on mean number of branches per plant as influenced periodically by various treatments are presented in Table 1. It would revealed that the number of branches increased from 5.91 at 75 days after sowing to 22.12 at harvest of crop. Sowing of cotton at 25th MW produced maximum number of branches plant-1 (25.7) and revealed that the number of branches was significantly affected due to different sowing times. The next sowing times in order of sequence were 24th, 26th and 27th MW sowings. Similar result was Munk (2001), Patil et al., (2009)

The differences in the mean number of branches per plant due to varieties were significant at all the crop growth stages. The higher number of branches plant ${ }^{-1}$ produced with Ajeet-155 variety (25.47) over rest of the varieties (Table 1). The next varieties in order of sequence were Rashi-2 and Mallika.

The interaction between sowing times and varieties were significant for mean number of branches per plant at harvest. The variety Ajeet-155 when sown during $25^{\text {th }} \mathrm{MW}$ recorded higher number of branches per plant at harvest. This might be due to varietal performance to interaction of radiation during kharif.

\section{Number of boll per plant}

The data pertaining to mean number of boll per plant at harvest as influenced by different treatments are presented in Table 1. The result revealed that the mean number of boll per plant at harvest was 31.37.

The mean number of boll per plant at harvest as influenced by sowing times given in Table 1. It was significantly influenced by different sowing times. Sowing during $25^{\text {th }} \mathrm{MW}$ recorded maximum number of boll per plant (36.22). This was due to lower temperature during flowering resulted in low flower drop and more boll setting during kharif season and followed sowing times in order of sequence were 24th, 26th and 27th MW sowings. 
Table.1 Mean growth characters of Cotton as influenced by different treatments

\begin{tabular}{|c|c|c|c|c|c|}
\hline \multirow[t]{2}{*}{ Treatments } & \multicolumn{5}{|c|}{ Growth characters at harvesting stage } \\
\hline & $\begin{array}{c}\text { Plant Height } \\
(\mathrm{cm})\end{array}$ & $\begin{array}{l}\text { No. of } \\
\text { branches } \\
\text { per plant }\end{array}$ & $\begin{array}{c}\text { No. of boll per } \\
\text { plant }\end{array}$ & $\begin{array}{c}\text { Days } \\
\text { required to } \\
\text { flowering }\end{array}$ & $\begin{array}{c}\text { Days required } \\
\text { to maturity (1st } \\
\text { picking) }\end{array}$ \\
\hline \multicolumn{6}{|c|}{ Date of sowing } \\
\hline $\mathrm{D}_{1}(24 \mathrm{MW})$ & 136.88 & 21.13 & 30.08 & 57 & 152 \\
\hline $\mathrm{D}_{2}(25 \mathrm{MW})$ & 145.73 & 25.71 & 36.22 & 57 & 148 \\
\hline $\mathrm{D}_{3}(26 \mathrm{MW})$ & 140.67 & 23.83 & 32.34 & 54 & 142 \\
\hline $\mathrm{D}_{4}(27 \mathrm{MW})$ & 130.97 & 18.70 & 26.84 & 54 & 138 \\
\hline SE. \pm & 0.037 & 0.006 & 0.020 & 0.019 & 0.019 \\
\hline CD. at $0.05 \%$ & 0.11 & 0.022 & 0.060 & 0.064 & 0.064 \\
\hline \multicolumn{6}{|c|}{ Variety } \\
\hline$V_{2}($ Ajit-155) & 140.13 & 25.47 & 32.50 & 57 & 144 \\
\hline $\mathrm{V}_{1}$ (Mallika) & 137.38 & 19.25 & 30.32 & 56 & 145 \\
\hline$V_{3}$ (Rashi-779) & 138.11 & 21.65 & 31.29 & 54 & 147 \\
\hline SE. \pm & 0.032 & 0.003 & 0.035 & 0.014 & 0.014 \\
\hline CD. at $0.05 \%$ & 0.094 & 0.01 & 0.051 & 0.042 & 0.042 \\
\hline \multicolumn{6}{|c|}{ Interaction (D X V) } \\
\hline SE. \pm & 0.064 & 0.013 & 0.035 & 0.056 & 0.056 \\
\hline C. D. at $0.05 \%$ & 0.19 & 0.040 & 0.10 & 0.167 & 0.167 \\
\hline G.mean & 138.54 & 22.12 & 31.37 & 55 & 145 \\
\hline
\end{tabular}

Table.2 Yield of cotton $\left(\mathrm{Kg} \mathrm{ha}^{-1}\right)$ as influenced by different treatments

\begin{tabular}{|c|c|c|c|c|}
\hline Treatments & $\begin{array}{c}\text { Seed cotton } \\
\text { Yield }\left(\mathrm{Kg} \mathrm{ha}^{-1}\right)\end{array}$ & $\begin{array}{c}\text { Straw Yield } \\
\left(\mathrm{Kg} \mathrm{ha}^{-1}\right)\end{array}$ & $\begin{array}{l}\text { Heat use efficiency } \\
\text { seed cotton yield }\end{array}$ & $\begin{array}{c}\text { Growing } \\
\text { degree days }\end{array}$ \\
\hline \multicolumn{5}{|c|}{ Date of sowing } \\
\hline $\mathrm{D}_{1}(24 \mathrm{MW})$ & 1779 & 4609 & 0.34 & 5278.8 \\
\hline $\mathrm{D}_{2}(25 \mathrm{MW})$ & 1888 & 4926 & 0.37 & 5146.3 \\
\hline $\mathrm{D}_{3}(26 \mathrm{MW})$ & 1807 & 4744 & 0.37 & 4903.7 \\
\hline $\mathrm{D}_{4}$ (27 MW) & 1568 & 3830 & 0.32 & 4825.3 \\
\hline SE. \pm & 38.92 & 40.53 & - & - \\
\hline CD. at $5 \%$ & 114 & 118.7 & - & - \\
\hline \multicolumn{5}{|c|}{ Variety } \\
\hline $\mathrm{V}_{1}$ (Ajit-155) & 1968 & 4633 & 0.39 & 5028.5 \\
\hline $\mathrm{V}_{2}$ (Mallika) & 1571 & 4406 & 0.31 & 5018.6 \\
\hline $\mathrm{V}_{3}($ Rashi-779) & 1744 & 4543 & 0.35 & 5068.6 \\
\hline SE. \pm & 33.70 & 35.10 & - & - \\
\hline CD. at 5\% & 98.7 & 102.8 & - & - \\
\hline \multicolumn{5}{|c|}{ Interaction (D X V) } \\
\hline SE. \pm & 67.4 & 70.2 & - & - \\
\hline CD. at $5 \%$ & 197.4 & 205.5 & - & - \\
\hline G. mean & 1761 & 4527 & 0.35 & 5038.5 \\
\hline
\end{tabular}


Table.3 Correlation co-efficient exhibited by weather parameters prevailed in different varieties with growth and yield characters at harvesting stage (2016-17)

\begin{tabular}{|c|c|c|c|c|c|c|}
\hline Parameters & $\begin{array}{l}\text { Plant } \\
\text { height }\end{array}$ & $\begin{array}{c}\text { Number of } \\
\text { branches/plant }\end{array}$ & $\begin{array}{l}\text { Number of } \\
\text { bolls/plant }\end{array}$ & $\begin{array}{l}\text { Seed cotton } \\
\text { yield }\end{array}$ & Straw yield & $\begin{array}{l}\text { Biological } \\
\text { yield }\end{array}$ \\
\hline \multicolumn{7}{|c|}{$V_{1}(A j i t$ 155) } \\
\hline Rainfall & $0.737 * *$ & $0.950 * *$ & $0.865 * *$ & $0.781 * *$ & $0.940 * *$ & $0.983 * *$ \\
\hline Tmax & $0.959 * *$ & $0.982 * *$ & $0.965 * *$ & $-0.679 *$ & -0.084 & -0.247 \\
\hline Tmin & -0.399 & 0.066 & -0.008 & $0.667 *$ & $0.964 * *$ & $0.974 * *$ \\
\hline RH-I & $0.807 * *$ & $0.988 * *$ & $0.949 * *$ & $0.766^{* *}$ & $0.962 * *$ & $0.997 * *$ \\
\hline RH-II & $-0.939 * *$ & $-0.766 * *$ & $-0.711 *$ & $0.721 *$ & $0.964 * *$ & $0.987 * *$ \\
\hline BSS hrs/day & 0.204 & $0.998 * *$ & -0.172 & $-0.759 * *$ & $-0.959 * *$ & $-0.993 * *$ \\
\hline \multicolumn{7}{|c|}{$\mathbf{V}_{2}$ (Mallika) } \\
\hline Rainfall & $0.729 * *$ & $0.675^{*}$ & $0.916^{* *}$ & $0.934 * *$ & $0.592 *$ & $0.832 * *$ \\
\hline Tmax & $0.956 * *$ & $0.898 * *$ & $0.966 * *$ & -0.394 & $-0.888 * *$ & $-0.650 *$ \\
\hline Tmin & -0.410 & -0.234 & 0.079 & $0.871 * *$ & 0.448 & $0.727 * *$ \\
\hline RH-I & $0.800 * *$ & $0.809 * *$ & $0.979 * *$ & $0.906 * *$ & $0.606 *$ & $0.821 * *$ \\
\hline RH-II & $-0.939 * *$ & $-0.684^{*}$ & $-0.702 *$ & $0.898 * *$ & 0.523 & $0.778 * *$ \\
\hline BSS hrs/day & 0.204 & -0.259 & -0.137 & $-0.912 * *$ & -0.580 & $-0.813 * *$ \\
\hline \multicolumn{7}{|c|}{$\mathbf{V}_{3}$ (Rashi-2) } \\
\hline Rainfall & $0.951 * *$ & $0.948 * *$ & $0.965 * *$ & $0.982 * *$ & $0.901 * *$ & $0.972 * *$ \\
\hline Tmax & $0.987 * *$ & $0.968 * *$ & $0.887 * *$ & -0.362 & 0.211 & -0.018 \\
\hline Tmin & 0.034 & -0.010 & 0.147 & $0.949 * *$ & $0.961 * *$ & $0.997 * *$ \\
\hline RH-I & $0.982 * *$ & $0.945 * *$ & $0.916^{* *}$ & $0.994 * *$ & $0.889 * *$ & $0.970 * *$ \\
\hline RH-II & $-0.801 * *$ & $-0.867 * *$ & $-0.791 * *$ & $0.973 * *$ & $0.934 * *$ & $0.990 * *$ \\
\hline BSS hrs/day & 0.062 & 0.257 & 0.338 & $-0.988 * *$ & $-0.906 * *$ & $-0.978 * *$ \\
\hline
\end{tabular}

(* Significant at $5 \%, * *$ Significant at $1 \%$ )

Similar result Mahmood-ul-Hassan (2003), Patil et al., (2009). The result showed different varieties was presented in Table 1 . It was significantly influenced by different varieties among variety Ajeet-155 recorded maximum number of boll per plant (32.50) due to less flower drop and more boll setting and minimum by Mallika (30.32) due to their respective yield potentials.

The interaction between varieties and sowing times were significant for number of boll per plant at harvest.

A cotton variety Ajeet-155 when sown during $25^{\text {th }} \mathrm{MW}$ registered the highest number of boll per plant.

\section{Days required to flowering}

The data pertaining to days required to flowering as influenced by different treatments was given in Table 1. The days required to flowering was significantly influenced due to sowing times and varieties. The mean days required to attend the stage was 55 days to flowering. The result shown that cotton sown during $26^{\text {th }}$ and $27^{\text {th }} \mathrm{MW}$ recorded minimum days required to flowering (54) and maximum for $24^{\text {th }}$ and $25^{\text {th }}$ MW (57) due to favourable climatic conditions.

The result shown that days required to flowering were significantly influenced due to varieties. A variety Ajit-155 recorded 
maximum days required to flowering (57) and minimum for variety Rashi-2 (54). This was due to the weather conditions prevailed during crop growth period. The interaction between varieties and sowing times were significant for mean days required to flowering.

\section{Days required to maturity ( $1^{\text {st }}$ picking)}

The data pertaining to days required to maturity ( $1^{\text {st }}$ picking) as influenced by different treatments was given in Table 1.

The days required to maturity ( $1^{\text {st }}$ picking) was significantly influenced due to sowing times and varieties. The data revealed that the mean days required to maturity $\left(1^{\text {st }}\right.$ picking) was 145 days.

The result shown that cotton sown during $27^{\text {th }}$ MW recorded minimum days required to maturity ( $1^{\text {st }}$ picking) (138) and maximum for $24^{\text {th }} \mathrm{MW}$ (152) due to favourable weather conditions.

The result shown that days required to maturity ( $1^{\text {st }}$ picking) were significantly influenced due to varieties. A variety Rashi-2 recorded maximum days required to maturity ( $1^{\text {st }}$ picking) (147) and minimum for variety Ajit-155 (144).

This was due to the meteorological conditions prevailed during crop growth period. The interaction between varieties and sowing times were significant for mean days required to maturity ( $1^{\text {st }}$ picking).

\section{Yield}

The data presented in Table 2 indicated that mean seed cotton and straw yield was 1761 $\mathrm{kg} \mathrm{ha}^{-1}$ and $4527 \mathrm{~kg} \mathrm{ha}^{-1}$ respectively. Seed cotton and straw yield was influenced by different treatments.
The data pertaining to seed cotton and straw yield of cotton at harvest as influenced by sowing times are presented in Table 2. It was significantly influenced by different sowing times. Sowing of cotton at $25^{\text {th }} \mathrm{MW}$ recorded maximum seed cotton and straw yield (1888 $\mathrm{kg} \mathrm{ha}{ }^{-1}$ ) and (4926 $\mathrm{kg} \mathrm{ha}^{-1}$ respectively followed sowing times in order of sequence were $24^{\text {th }}, 26^{\text {th }}$ and $27^{\text {th }}$ MW sowings. Similar result was reported by Patil et al., (2009), Mahmood-ul-Hassan et al., (2003).

The data pertaining to seed cotton and straw yield of cotton at harvest as influenced by different varieties are presented in Table 2. It was significantly influenced by varieties. A variety Ajeet-155 recorded maximum seed yield (1968 kg ha ${ }^{-1}$ ) and straw yield (4633 kg $\mathrm{ha}^{-1}$ ) was superior over rest of the varieties and lowest by Mallika (1571 $\mathrm{kg} \mathrm{ha}^{-1}$ ) and $\left(4406 \mathrm{~kg} \mathrm{ha}^{-1}\right)$. This was due to less flower drop, more number of branches and number boll plant ${ }^{-1}$ helped in more seed cotton yield $\left(\mathrm{kg} \mathrm{ha}^{-1}\right)$.

The effect of interaction between varieties and sowing times at harvest were found significant for seed cotton and straw yield and the relevant data are presented in table 2 .

\section{Heat use efficiency (HUE) and Growing degree days (GDD)}

The result given in Table 2 indicated that mean Heat use efficiency and Growing degree days was required of $\left(0.35 \mathrm{~g} \mathrm{~m}^{-2}\right.$ per $\left.{ }^{\circ} \mathrm{C}\right)$ and (5038.5 ${ }^{\circ} \mathrm{C}$ days) respective for different treatments.

At maturity, HUE for seed cotton yield was significantly higher $\left(0.37 \mathrm{~g} \mathrm{~m}^{-2}\right.$ per $\left.{ }^{\circ} \mathrm{C}\right)$ for $\mathrm{D}_{2}$ $\left(25^{\text {th }} \mathrm{MW}\right)$ and $\mathrm{D}_{3}\left(26^{\text {th }} \mathrm{MW}\right)$ sown crop as compared to rest of treatment. Among cultivars, Ajit-155 had significantly higher heat use efficiency $\left(0.39 \mathrm{~g} \mathrm{~m}^{-2}\right.$ per $\left.{ }^{\circ} \mathrm{C}\right)$ followed by Rashi-779 (0.35 $\mathrm{g} \mathrm{m}^{-2}$ per $\left.{ }^{\circ} \mathrm{C}\right)$ 
and Mallika $\left(0.31 \mathrm{~g} \mathrm{~m}^{-2}\right.$ per $\left.{ }^{\circ} \mathrm{C}\right)$ for seed cotton yield production. Growing degree days (GDD) for seed cotton yield was found maximum (5278.8 ${ }^{\circ} \mathrm{C}$ days) for $\mathrm{D}_{1}$ sown crops. In case of cultivars, Rashi-779 had highest Growing degree days (GDD) (5068.6 ${ }^{\circ} \mathrm{C}$ days) for seed cotton yield production. The minimum growing degree days (GDD) was found in Mallika for seed cotton yield production. Higher HUE and GDD in timely sown could be attributed to the highest seed cotton yield. As the temperature was optimum throughout growing period crop utilized heat more efficiently and increased biological activity that confirm higher yield.

\section{Correlation coefficient}

\section{Growth characters}

The rainfall, maximum temperature, morning relative humidity and bright sunshine hours was significantly positive correlated with plant height, number of branches per plant and number of boll per plant of Ajeet-155, Mallika and Rashi-2 (779) varieties respectively at harvesting stage While minimum temperature and afternoon relative humidity was negative correlation with growth characters.

\section{Yield}

The rainfall, minimum temperature, $\mathrm{RH}-\mathrm{I}$ and RH-II has been positively correlated with seed, straw and biological cotton yield of Ajit-155, Mallika and Rashi-2 (779) varieties, while maximum temperature and BSS has negatively correlated of Ajit-155, Mallika and Rashi-2 (779) varieties respectively.

Sowing of cotton during different sowing times significantly influenced growth and yield characters. A plant height, number of branches plant ${ }^{-1}$, number of boll plant ${ }^{-1}$ production were significantly more when cotton was sown during $25^{\text {th }} \mathrm{MW}$ and variety Ajit-155 was sown during $25^{\text {th }} \mathrm{MW}$ favoured most of the growth and yield contributing characters. Rainfall, maximum temperature, morning relative humidity was positively correlated, whereas, BSS and afternoon relative humidity was negatively correlated with plant height, number of branches per plant and number of boll per plant at harvesting stage. The rainfall, minimum temperature, RH-I and RH-II has been positively correlated with seed, straw and biological cotton yield of Ajit-155, Mallika and Rashi-2 (779) varieties.

\section{References}

Anonymous, 2015. Food and Agriculture Organisation, Statistical Department, India (FAO).

Awan H., Awan, I., Mansoor, M., Khan, E.A. and Khan, M.A. 2011. Effect of sowing time and plant spacing on fiber quality and seed cotton yield. Sarhad J. Agric. Vol.27, No.3: 411-413

Doorenbos, J. and Pruitt, W.O. 1984. Guidelines for predicting crop water requirements. FAO Irrigation and Drainage paper 24. The United Nations, Rome.

ICAC, 2007. (International Cotton Advisory Committee, United States Of America) Global warming and cotton production Part 1. In: ICAC Recorder, 25 (4): $12-16$.

Jadhav, M. G, 2010. Research work carried out during the year 2009-10. Submitted to food cash crops sub-committee (R. R. C), 17-24.

Jadhav, S. T. 2014. Effect of weather parameters on growth and development of Bt cotton (Gossypium Spp.) M.Sc. (Agricultural meteorology) thesis. VNMKV, Parbhani.

Mahmood-ul-Hassan, Nasrulla, M., Iqbal, M. Z. and Taj M. 2003. Effect of different 
sowing dates on cotton (Gossypium hirsutum L.) cultivars. Asian Journal of plant science. 2(6): 261-263.

Munk, D. S. 2001. Plant density and planting date impact on pima cotton development. http://regional.org.au/au/ asa/2001/p/13/munk.htm.

Patil, D. V., Deosarkar D. B. and Patil, S. G. (2009). Study of $\mathrm{B} t$ and non-B $t$ cotton hybrids for yields and quality characters under normal and delay-sown condition. J. cotton Res. Dev. 23(2): 199-203.

Reddy, K. R., Davidonis, G. S., Jhonson, A. S. and Vinyard, B. T. 1999. Temperature. Regime and carbon dioxide enrichment alter cotton boll development and fiber properties. Agron J., 91: 851-858.

Reddy, K. R., Robana, R. R., Hodges, H. F., Lie X. J. and Mckinion, J. M. 1998. Interactions of $\mathrm{CO}_{2}$ enrichment and temperature on cotton growth and leaf characteristics. Environ Exp Bot., 39: 117-129.

Ryan, P. V. 2005. Cotton boll maturation affected by temperature variation. Agron. J., 97: 494-499.

Young, E. F., Taylor, R. M. and Petersen, H. D. 1980. Day degree units and time in relation to vegetative development and fruiting for three cultivars of cotton. Crop Science, vol. 20 No. 3, p. 370-374.

\section{How to cite this article:}

Dakhore, K.K. and Kadam, Y.E. 2018. Effect of Weather Parameters on Crop Growth, Development and Yield of Kharif Cotton Varieties under Extended Sowing Times. Int.J.Curr.Microbiol.App.Sci. 7(12): 3411-3418. doi: https://doi.org/10.20546/ijcmas.2018.712.390 